\title{
East Asia
}

\author{
SHAUN BRESLIN
}

The task of writing about democratization in East Asia as a whole is a hugely problematic one. It is a region that contains massive diversity in political and economic systems and one that remains in a state of considerable flux and transition. A key element in this transition is the end of the Cold War, and the resulting reduction in US tolerance of authoritarianism so long as that authoritarianism was overtly anti-communist. It is also a region where, as in East and Central Europe, communist party states are struggling with the transition from centrally planned socialist economies - though, by contrast with the European examples, and with the exception of Outer Mongolia, this is a transition that has not been accompanied by the end of communist party rule and a parallel process of democratic transition. And it is also a region where financial crises and economic recession have dominated political activity and discourse for half a decade. Perhaps more than in any other region considered in this volume, the overarching framework for political activity here is shaped by the transition from Cold War strategic structures to globalized economic structures.

A cursory analysis of the Freedom House ratings for states in the region gives some indication of the problems of considering the region as a whole (see Table 11.1). At one extreme we have the established democracy of Japan though even here, the transition from managed factionalism within the structure of rule by the Liberal Democratic Party (LDP) to conflictual factionalism and political fragmentation in the post-LDP coalition governments has created new challenges to democratic politics. There is then a second set of states that have seen considerable moves towards 
Table 11.1 Freedom House ratings for East Asian countries, 2001-2

\begin{tabular}{lcccc}
\hline Country & $\begin{array}{c}\text { Political } \\
\text { rights }\end{array}$ & $\begin{array}{c}\text { Civil } \\
\text { liberties }\end{array}$ & Rating & $\begin{array}{c}\text { Per capita GNP } \\
\text { (PPP US\$) }\end{array}$ \\
\hline Burma & 7 & 7 & NF & 1,500 \\
Cambodia & 6 & 5 & NF & 1,500 \\
China (PRC) & 7 & 6 & NF & 4,300 \\
Indonesia & 3 & 4 & PF & 3,000 \\
Japan & 1 & 2 & F & 27,200 \\
Korea (North) & 7 & 7 & NF & 1,000 \\
Korea (South) & 2 & 2 & F & 18,000 \\
Laos & 7 & 6 & NF & 1,630 \\
Malaysia & 5 & 5 & PF & 9,000 \\
Mongolia & 2 & 3 & F & 1,770 \\
Philippines & 2 & 3 & $\mathrm{~F}$ & 4,000 \\
Singapore & 5 & 5 & PF & 24,700 \\
Taiwan & 1 & 2 & F & 17,200 \\
Thailand & 2 & 3 & F & 6,600 \\
Vietnam & 7 & 6 & NF & 2,100 \\
\hline
\end{tabular}

Notes: $\mathrm{F}=$ Free; $\mathrm{PF}=$ Partly Free $; \mathrm{NF}=$ Not Free. $\mathrm{GNP}=$ Gross National Product; PPP = purchasing power parity. While PPP figures provide a base for comparative analysis, they considerably inflate the exchange rate GNP of non-market economies - the figure for China here is nearly 4 times the official Chinese figure.

Source: A. Karatnycky, 'The 2001 Freedom House Survey', Journal of Democracy (2002), 13:1, 108-9; GNP estimates from CIA, The World Factbook 2002, at www.cia.gov/cia/publications/factbook/index.html.

democratization - in South Korea, where military rule has given way to transfers of power via the ballot box as an accepted feature of political life; in Outer Mongolia, which has moved from authoritarian to 'free' as a result of the end of communist party rule and the election of the Democratic Union Coalition in 1996; in Indonesia, which while still only partially free and retaining considerable authoritarianism has nevertheless moved to partially free; and in the Philippines and Thailand, which have moved from partially free to free; and perhaps most notably in Taiwan, which saw the end of martial law and a transition from Guomindang single-party rule to the presidency of the Democratic Progressive Party's Chen Shui-bian in little over a decade. 
But before we proclaim the end of history and applaud the transition to democracy, we should consider at least three other sets of states in the region. At the other extreme from Japan, the rigidly authoritarian states of Burma and North Korea remain, perhaps more than any other states in the world, as impervious to the international system as can be today. A second set of authoritarian states is found in the residual communist party states of Laos, Vietnam and China, where political and social freedom remained strictly restrained despite increased economic freedom as a result of marketization and the retreat from socialism. A third set, on its own, is Singapore, where the electoral system should not be allowed to disguise a limited franchise, and strict state controls over social freedom. Finally, there is a set of regional states that have moved away from freedom and democratization. For example, Cambodia, which has tightened authoritarian rule despite partial freedom status in the mid-1990s; and Malaysia, which has moved from free in 1972 to partially free today. We should perhaps also include here Hong Kong, which while never having had a full and free franchise, has seen even limited democratization circumscribed by the reversion to Chinese sovereignty in 1997.

There has been no single wave of democratization in Asia, then. Though it is possible to draw comparisons from the similar processes in the transition from military rule in South Korea and Taiwan (Wu 1998; Potter 1996) - which have both occurred in the context of relations with the US and relations with rival regimes to the north - discerning region-wide patterns is not so much problematic as impossible. It is possible, of course, to provide in a chapter of this sort a short potted tour of democratization (and the lack of it) in each state - but that would be unsatisfactory. Instead, the chapter seeks to draw out conceptual and methodological issues in considering democratization in Asia - issues that will vary in importance and relevance in each regional state. At its heart is a concern with avoiding concept stretching - with avoiding the pitfall of seeing something that is familiar in the context of democratization and assuming that it functions in the same way in Asia (and indeed in other areas of the world) as it does in the West. 


\section{Asian values and the politics of rejection: what Asia isn't}

A clear notion of what East Asia means in terms of studies of democratization in large part emerges from the 'Asian values' debate, which in itself has been spurred by Huntington's (1996) notion of a 'clash of civilizations'. The idea that there are a set of Asian values that are effectively different from Western traditions has some attraction attraction in the West, as it makes Asia easier to bracket as 'different', and attraction in some parts of Asia at least, as it provides a partial justification for the authoritarian nature of many Asian regimes, and for infringements on human rights in several of them.

The argument for a concept of Asian values can be simplified in a very straightforward way. Asian societies, it is argued, have developed on a very different trajectory from those in the West, and have different philosophical and/or historical cultural roots. In the West, the emergence of democracy and notions of rights were largely devised to provide a bulwark for the individual from the state. And democracy, as practised in the West, now takes place in the context of post-industrialized societies with well-established procedures and norms for the conduct of political life.

In Asia, by contrast, the roots of the contemporary system are very different. For example, the traditional Confucian concept of society (which predominated in China, Korea and, to a lesser extent, Japan) was one based on harmony and unity between state and people - the idea of creating a bulwark against the state was anathema, as state and society should be one. Where a discourse on rights existed, it was largely conducted in terms of collective rights, where the interests of the collective - be that collective the family, the state, or even socialism - were far more important than those of any individual (Weatherley 1999).

In considering a truly comparative study of democratization, there should be sympathy for the understanding that democracy and democratization are culturally, historically and politically embedded. But the idea that there is a single set of 'Asian values' that provides a lens through which we study democracy in East Asia should be treated with considerable scepticism. In some respects, the concept helps 
our understanding by establishing a notion of the 'other' in which Asian debates over democracy take place. The concept of Asia that the Asian values debate promotes is a rejectionist one - what is shared is a rejection of the imposition of what is considered to be a 'Western' concept of politics and polity that has developed and emerged in specific Western contexts that are not applicable to Asia. This understanding is also reflected in other realms of politics - for example, a rejection of the neo-liberal 'Western' economic policies as embodied in the policies of the International Monetary Fund (IMF) and the Word Trade Organization (WTO), and a rejection by some of the post-industrialized and seemingly unfair environmental strategies pursued by many Western states.

This rejectionist stance is perhaps best embodied by attempts to create a cognitive understanding of a region called 'East Asia'. This understanding is largely predicated on a rejection of the Asia Pacific Economic Co-operation (APEC) definition of a region that includes not only the Asian states of Asia, but also the Australasian states, and those states on the Pacific seaboard of the Americas. The proposals of the then Malaysian premier Mohammed Mahathir to establish an East Asian Economic grouping (now formally the East Asian Economic Caucus within APEC) is a good example of defining a region by what it is not (Higgott and Stubbs 1995). So too was the impulse to decide on an Asian entity that would negotiate with the European Union in the Asia Europe Meeting (ASEM) process, which perhaps for the first time forced 'Asia' to decide what it was - and in the process, rejected both the Indian sub-continent and Australasia as comprised in Asia.

So what the Asian values debate helps clarify is what Asia is not - it is not the advanced industrialized and democratized West. It is also framed by a world-view in many Asian governmental elites that is suspicious of the motives of the West in trying to condition developments in the region. And in many cases, the West is synonymous with the United States; and for many regional critics of globalization, it is nothing more than Americanization. But while it might help us understand what Asia is not - what it rejects - it does not help us understand what Asia is. On one level, the concept that there is a single set of Asian values 
that spans the entire region obfuscates more than it clarifies. At worst, it leans towards an assessment of democratization in the region that treats it as a single entity, rather than reflecting the immense diversity that exists.

On another level, the search for explanations in traditional Asian values can be rather problematic. For example, in searching for the roots of liberal thoughts in Confucianism, Goldman (1994) concludes that the basic tenets of Confucianism are not necessarily incongruent with concepts of human rights. This may indeed be true, and Sen (1997) has argued forcefully against the Asian values concept as a justification for authoritarianism. But in some respects, searching for the roots of contemporary authoritarianism or contemporary democracy in The Analects is akin to searching for the roots of democracy in Britain in the belief systems of the Druids. In the intervening years, the structure of state power in China and in other states has done much to shape the way in which traditional ideas have become transformed into contemporary state systems. So rather than emphasize too strongly the historical philosophical roots of contemporary policy and intellectual discourse, it is worth turning to other factors that should inform the way in which we study contemporary democratization in East Asia, and which, in turn, could help us understand some of the preconditions upon which studies of democratization in the West are constructed.

\section{The comparative method and democratization}

First, we should simply not ignore the fact that comparative analyses need to take care when they decide on the unit of comparison. Taking democracy in the West as our benchmark could lead to a tendency to compare other parts of the world now with democracy in the West now. I suggest that this can lead to a false set of comparisons, and we should rather consider the correct temporal comparison. The emergence of democracy in the West was a slow and protracted evolutionary process. So too was the Western industrial revolution. Analyses of democratization and human rights in, for example, the United Kingdom during the industrial 
revolution would not necessarily generate favourable comparisons with the situation in the UK today. Accordingly, and in keeping with the general orientation of this book, we should consider comparison between comparable processes of democratization qua processes, accepting that the experience in the West at similar phases of the national and industrial revolutions might generate sounder foundations for comparison than judging unlike with unlike within an arbitrarily chosen common temporal framework.

We have noted above the disparities that exist within Asia - ranging from the relatively liberal political and economic system of Japan to the authoritarian (by any comparison) Burmese system. Leaving aside the most 'advanced' industrialized economies of Japan, Korea and Taiwan, and ignoring the rather strange anomalies of city states like Singapore and Hong Kong, gives us a situation where three key transitions have yet to take place in much of Asia economic revolution, national revolution and a Polanyiesque great transformation (after Polanyi 1944). ${ }^{1}$

First, we need to recognize that economic underdevelopment remains the major context for politics in much of the region. We must not be too heavily influenced by the growth rates recorded by many Asian states in the last two decades - if you produce one tractor one year, and two the next, you register a growth rate of 100 per cent, but still have only three tractors. For example, despite near-double-digit growth rates in China for two decades, and the fact that the sheer size of the country generates an enormous Gross Domestic Product (GDP), per capita GDP is still below Russia's widely considered to be the stock negative comparison in terms of economic fortunes in the transition from socialism.

And of course, in 1997, the Asian financial crises placed a new dimension on this issue of economic development. On one level, the crises promoted the importance of democratization, in terms of a reaction against the 'crony capitalism' that some argued had at least contributed to the crises (Wei and Dievers 2000). Crises and economic recession in many regional states impacted on the newly expanded middle classes, who had been the beneficiaries of the precrises boom. It is from within these groups that many of the pressures for change now emanate in Thailand, Indonesia and Malaysia. Similar pressures from the middle class can 
be observed in Hong Kong, where the educated middle classes are feeling the impact of economic recession for the first time in generations. Business elites too have been forced to rethink their position and their relationship with the state as a result of the crises - indeed, in Thailand a representative of the business elite was elected to lead the country. Rather than allow politicians to run the country on their behalf, the Thai elites appear to have decided to run it themselves!

There have also been uncertain or ambivalent consequences of crisis. Hewison (2001) notes that in Thailand there has been a turn towards local identities and localism as a response to national crisis. Such localism could provide the basis for a more participatory democratization at the grass-roots level. But it is also predicated on a concern that Thai culture is under attack from the agencies of international capitalism in the shape of World Bank and IMF recovery projects - projects that 'impose' alien Western values and practices. In this respect, nationalism as a response to crises has been an important political change in three main ways, as state elites have tried to turn the blame for crises away from themselves and on to 'outside' groups. First, the blame for the crises has been placed on foreign banks and investors, who moved their portfolios out of the region at speed, triggering financial chaos. Second, with the support of state elites, it has reinforced the rejectionist stance towards the West detailed above. Third, and again with the support of state elites, most notably in Indonesia, it has generated a wave of ethnic violence against minority groups - particularly the overseas Chinese.

For observers it is easy to point to the role of the state in attempting to deflect criticism for their own actions or inactions - and to an extent this is a valid argument. But we should not simply ignore the real concerns of many within the region - real concerns on one level that the West is imposing its values on countries with different historical, philosophical, cultural and political roots. But also real concerns that this thing called globalization is really impinging on sovereignty, or political self-determination. What point is there in voting for one party or another if the fundamental economic strategy of whichever government is elected is shaped by the IMF and the World Bank, or by the investment 
and disinvestment strategies of major external corporations and investment brokers? In this respect, there is a real feeling of disempowerment amongst many in the region, and a concern that globalization has resulted in a 'democratic deficit' - particularly amongst many in the intellectual community, as is perhaps best articulated by the work produced in connection with the 'Focus on the Global South'. ${ }^{2}$

Finally, the crises have impacted hardest on rural farmers and the urban working classes - many of whom are now the urban unemployed. These groups are the least represented in democratic politics, both in terms of formal political parties and organizations, and in terms of participation in pressure groups and civil society organizations. While they were perhaps never particularly well represented in many regional states, their under-representation now at a time when they need it more than ever is an important consideration in democratic politics.

Of course, it is entirely right and justifiable to consider the growth of civil society as an indicator of democratization and progress. But in doing so, we should not ignore the issue of the balance of representation and the extent to which democratization permeates all sectors of society. I suggest, then, that much of the activity of civil society in the region represents the interests of the middle classes perhaps even over-represents those interests, while business elites retain an even stronger access to the political process and the representation of interest. A key challenge that remains is to ensure that democracy becomes more inclusive, more participatory, and more representative of the interests of those who may not be formally disenfranchised, but are often largely excluded from the political process.

We should remember that the national revolution in many Asian states is incomplete. Or at the very least, the processes of nation-building and state consolidation in many Asian states are still ongoing. The concept of a Vietnamese nation, for example, is still relatively new by historical standards, and largely a consequence of the dual processes of colonization and decolonization. Indonesia, as a political entity, has been challenged by the secession of East Timor, raising the fear in some (and hope in others) that the Indonesian state may further fragment into ethnically defined nation-states. And in Korea and China, there is the spectre 
of rival regimes claiming (though not always reciprocally) jurisdiction over a disputed national entity. Without a clear understanding of what constitutes the demos, constructing democracy is inherently problematic.

This immature realization of nationhood and statehood is often explained in terms of the end of the Cold War. And indeed, the end of the Cold War has played a key role. But in many respects, these issues are pre-Cold War in nature and owe much to the incomplete process of decolonization and nation-building that the onset of the Cold War interrupted.

Ethnic tensions - often closely related to this incomplete national revolution - also impinge on the evolution of democracy. The ethnic tensions that emerged during the financial crises, most notably in Indonesia, have already been mentioned. But even in more peaceful 'normal' times, resentment at the control of political power by dominant ethnic groups in Malaysia, Singapore and Indonesia, to name but three, undermines the legitimacy of the democratic polity.

But perhaps most fundamentally, we need to revisit the question of the way in which we study democratization and the basic premises on which many analyses are made. Take as a starting-point the classic text by Polanyi (1944). Almost implicitly, many studies of democratization assume the 'great transformation' as a given. The separation of public and private, of state and market, that occurred in Europe and other industrialized democracies established the basis of an understanding of the relationship between the state and non-state in which conceptions of democratization largely exist. In particular, when moving beyond an over-simple equation of elections with democracy, this separation of public and private becomes an essential component for understanding the state-society relationship.

But in reality, it was the 'great transformation' of industrialization in Europe in the nineteenth century that marked the 'singular departure' from the dominant norm by creating the institutional separation of society into an economic and a political sphere. For large parts of the world - not just in Asia - this transformation has not taken place, or is at best incomplete. The most obvious examples of this lack of separation are found in the communist party states within the region, where the socialist system all but demanded 
state control over society and economy. But it is also evident in other states - states that at first glance might appear to be Western-type democracies.

Van Wolferen (1990), for example, has long argued that analysts from the 'West' fail to understand Japan because they start with false assumptions. The concept of a separation between 'public' and 'private' that lies at the heart of some investigations of political economy is, according to van Wolferen, absent in Japan. Some have argued that this is a consequence both of the traditional understanding of 'economy' in East Asia and of the way in which market economies were established there. In Taiwan, where the residual authoritarian Guomindang government has been replaced through democratic elections, the former holders of a monopoly on state power retain strong control over key economic functions, through their ownership of large sections of the means of production.

Should this concern us as students of democratization, or is it an issue that we should leave for the political economists? Perhaps the details of state control and influence over the economy are best discussed elsewhere. But the important point is that analytical divisions between the national and the international, and between the political and the economic, obstruct a more nuanced understanding of domestic political processes and their impact on democratization in the contemporary world. As Gamble et al. (1996: 10) argue, 'The separation between the global and the local no longer holds, as the new hierarchies of the global economy cut across regional and national boundaries.' This being so, we should accept that a key, and neglected area of study in analyses of democratization is the ability of the demos to influence, through political processes, economic policy-making that impinges on the lives of national citizens - either through the structure of domestic political economies, or through the influence of external 'international' factors. In particular, a central concern here is the ability of those outside a narrow section of state elites and their allies to influence policy through democratic means, and the related question of transparency.

Robison (1988), for example, takes issue with claims that the Indonesian system does not work effectively. The point Robison wants to drive home is that political systems are 
designed to serve specific political interests. The Indonesian system might not have worked as external observers thought it should, but was in fact very successful in delivering the fruits of economic growth to members of the Indonesian elite. In particular, the politico-economic system was constructed to ensure that former President Suharto's family utilized political power to advance their economic status and control.

The Indonesian system, then, was deliberately opaque, and constructed to ensure that an elite group of insiders utilized a linkage between political power, economic policymaking, and state or family control over major sectors of the economy, to deliver rewards to themselves. The title of Harold Lasswell's Politics: Who Gets What, When and How? (1936) still offers an insightful starting-point for considerations of how political leaders make policies designed to benefit specific interests.

Perhaps Indonesia is an extreme case, though one that is remarkably similar in its deliberate opaqueness to the one that is emerging in China, as the transition from socialism creates a similar close relationship between elite policymakers and the beneficiaries of those policies (many of whom emerge from within the party-state system itself). However, even in the most 'liberal' - in that it looks like a Western democratic system - democracy in the region, in Japan, an understanding of the functioning of the domestic political economy raises a number of questions over the validity of deploying 'traditional' understandings of democratization.

It is helpful here to consider the conception of a 'capitalist developmental state' (CDS). The CDS system proved to be remarkably successful in generating economic growth in Japan and the newly industrialized countries (NICs) - policies that were partially emulated by later generations of developing states in the region. For Chalmers Johnson, a key component in this developmental strategy was the 'relative state autonomy' of elite bureaucrats who planned economic strategy (albeit in market-conforming manners) around perceived national interests - politicians reign but bureaucrats rule (Johnson 1987: 152). Irrespective of the result of democratic elections, an elite group of professional bureaucrats made economic policy based on their conceptions of the 
national interest, unconstrained by considerations of electoral popularity and insulated from the demands of societal interest groups. The politicians could worry about getting re-elected - in the Japanese case, by considering the interests of their local constituency rather than issues of wider national importance - and the bureaucrats would get on with running the economy. Thus, electors might be able to influence local developmental issues through the democratic process - to win a new train link with Tokyo, for example - but the overall direction of national economic planning continued unhindered by the inconvenience of democratic politics.

This system was facilitated by the eradication of powerful interest groups at the end of the Second World War through, first, defeat and then the US occupation in Japan, which resulted in the suppression of business and then workers' interests. The Japanese occupation in Korea resulted in weak societal or interest groups in the new South Korea. Meanwhile in Taiwan, similar groupings were eliminated following the arrival of the Guomindang and with the resulting party-state control of society and the economy. In all three cases, the state was emboldened by proclaimed strategies of national renewal and national mobilization to defend the new statist entities in the face of possible communist aggression in the region (Cumings 1987). And of course, in this Cold War context, being authoritarian, but anti-communist authoritarian, was often enough to qualify for considerable US economic aid, and Western tolerance of the lack of democratic forms.

In the case of Japan, the national interest was defined, according to Johnson (1981), by a policy community that encompassed a triad of bureaucrats, business interests and leaders of the LDP - the hegemonic party until the 1990s. A system of amakudari (descent from heaven) ensured that retired bureaucrats enjoyed second careers either within the business community or the LDP, while the industrial bureaux of the Ministry of International Trade and Industry (MITI) provided a formal framework within which business interests could influence the conception of national interest, and subsequently national economic planning.

What this means for students of democratization is that the opaque decision-making process was difficult for 
outsiders to penetrate. Elections, pressure groups and wider civil society had little chance to influence key economic policy-making that obviously impinged on the lives of national citizens. The system did not go unchallenged, as is perhaps best exemplified by the sporadic and violent protests in South Korea under military rule - perhaps most notably the Kwangju Incident of May 1980. But while it delivered significant economic growth, and as long as influential sectors of the populations were rewarded in the process, then the system was one that was at least tolerated by enough people to ensure its continuity. Even after the initial transition to democracy - albeit 'low intensity democracy' (Gills, Rocamora and Wilson 1993) in South Korea and Taiwan the decision-making process that created national economic strategy remained largely not transparent, and continued to be dominated by a relatively small group of insiders (though not everyone agrees with this assessment).

To be sure, this system has been challenged by the financial crises that highlighted the failings of crony capitalism - in states where transparency is not the norm, and the relationship between state and economy remains strong. Nevertheless, many Asian states do not have transparent policy-making processes in the Western mould (where there are limitations of transparency too). Thus of major importance to anyone wishing to consider the real extent of democratization in Asia should be those issues that often would fall under the ambit of political economy perspectives. It is there that, elections and the evolution of civil society groups notwithstanding, forces affecting the ability of the demos to influence the polis are most salient.

This also means that we should pay more attention to the influence of external factors, and not simply to the way that international human rights organizations, for instance, try to press for domestic political change. Those pressures are of course significant, not least because of the way in which the end of the Cold War has removed a key impediment to pressures for democratic change - particularly from the United States. But alongside those 'traditional' forms of pressure we need to consider the democratic implications of other external factors. For example, if transparency is important in democracy, then the policy initiatives of the IMF, the World Bank, and the WTO - all of whom call for 
greater transparency from governments - potentially have important implications. So too do the less overt pressures to conform to international norms of economic activity that largely reflect Western practices and interests. Their intention may not be explicitly to promote domestic democratization, but their consequences could have implications for democratization.

Moreover, the hand of the state is not just evident in the economy; judicial power - or more correctly, judicial independence - is relatively weak in many East Asian states. Furthermore, it can be, and is, used to prosecute political opponents - a notable recent example being the trial of the former Malaysian Deputy Prime Minister, Anwar Ibrahim, for calling for reform to the authoritarian system. According to the likes of Human Rights Watch, the Anwar case illustrates how, despite a prima facie legitimate judicial process, four notable features undermine the real democratic nature of the system: the lack of independence of judges appointed by the government, and dependent on them for promotion and advancement; the treatment of defence witnesses and defendants; constraints on the defence's chances of preparing adequate responses to the frequently changing charges; and the political atmosphere in which the trial was taking place.

On this last issue, we should focus on the extent to which democracy is constrained by a lack of free and plural information. Or in other words, can democracy exist without a fully informed demos? In the Malaysian case, Eng (1999) notes that a media that was once supportive of Anwar soon turned against him once the political atmosphere from the national government signalled an anti-Anwar turn. Only the relatively small Aliran Monthly, with an average circulation of 8,000 (which doubled during the Anwar trials) maintained a pro-Anwar stance during the trials, as other journals responded to government pressure and mounted a character assassination on Anwar (Eng 1999). Similarly, in Singapore, journalistic and academic freedom are strictly curtailed, with criticisms of the government and government policy frequently leading to censure and the termination of academic contracts (Rodan 2000).

Such limitations of information do not require state ownership of media or state control of academia - though 
they clearly help. In many respects, self-censorship results in an equally unfree and biased provision of information. Indeed, the more successful authoritarian states probably do not need to use heavy-handed tactics, as informal selfcensorship does the job of authoritarianism for them.

\section{The China syndrome}

At the risk of privileging the study of one regional state over others, it is worth considering the process of, and prospects for, democratization in China. This is partly because the Chinese case allows us to consider what democratization is for, and partly because it allows us to question some of the more traditional assumptions about the relationship between economic and political change.

First, then, we need to consider the purpose of democratization. Take as an example the introduction of competitive elections at county levels of authority since 1998. It might be the case that such elections allow Chinese voters to choose representatives who are not simply the candidates presented to them by the Chinese Communist Party (CCP). And indeed, in some cases, officially sanctioned CCP candidates have been defeated in these elections. Of course, critics can point to the fact that these county-level elections have little impact on the overall distribution of power in China - and it is a fair criticism. But even if such change in the distribution of power does occur in the long run, my concern here is with intentions rather than outcomes. In inception, and like the previous experiments with locallevel elections in 1980, officially sanctioned processes of democratization in China are not intended to pave the way for a challenge to CCP rule, but rather to strengthen it (Goodman 1997). For Kelliher (1997), they were based on an understanding that the political legitimacy of the CCP in the countryside had been eroding. Thus providing greater degrees of self-government was a key means of rebuilding legitimacy - not just in local governments in themselves, but more importantly in a political system dominated by one-party rule in general. Consequently, what might look like a move away from single-party rule from the outside is 
conceived as a means of strengthening single-party rule by its initiators.

A similar argument can be deployed for understanding the growth of civil society groups in China (Howell 1998). The original growth of civil society groups in China in the 1990s occurred because the CCP wanted to allow more leeway for officially sanctioned groups to act as a buffer between government and society. As with the introduction of elections, the growth of civil society in the long run may have unintended consequences for CCP rule. But again, the intention was not to weaken single-party rule, but to strengthen the legitimacy of single-party rule.

Second, the fact that China is in the process of a transition from a socialist economy and continues to enjoy impressive rates of economic growth and modernization allows us to test hypotheses formed to explain the relationship between economic and political change (see the discussion by Addison in Chapter 3). In contrast to the idea that economic reform and material advancement will lead to pressures for political reform from either an emerging middle class or the increasingly abandoned working class (or both), there are at least two possible alternative scenarios. For the time being, at least, rather than China's workers applying pressure for a more liberal political system, much of the evidence suggests that they are a force for conservatism. On one level, many workers, particularly from the state-owned sector, resent the fact that marketization has resulted in loss of jobs and the concomitant reduction of welfare provision. What many of them want is the certainty and basic standards of welfare associated with the old - not a return to the harsh days of the Cultural Revolution, but instead to a time after Mao when market reforms had been introduced, but their harsh impact on unprofitable producers had yet to become apparent. This seems far preferable to the uncertainty that the new economic order now appears to offer, or the even greater uncertainty that democratic political transformation could bring. Partly because of the example of former communist party states elsewhere, most notably the former Soviet Union, and partly as a result of official policy to reinforce the message, a transition from authoritarianism to democracy is often equated with economic decline and 
political chaos. It is not seen as a progressive and beneficial process.

On another level, the emergence of a new entrepreneurial class has also yet to translate into pressure for liberal democratic political reform. Indeed, many of the 'new class' have emerged from within the party-state system - they have used their positions within the political elite to create new positions as economic elites. And for the time being, using political power (or connections) to protect or enhance their economic position results in, at the very least, a continued acceptance of the established political system. At the same time, the growth of CCP membership to around 66 million is in large part due to emerging non-party economic elites joining the party to protect their own positions. They want to benefit from the connections and security offered by being 'part of the club' and insure themselves against residual suspicion directed at the role of private enterprise. As such, there is a coalescing of new and old elites around mutually beneficial political and economic orders.

Of course, not all new elites join the party. And ultimately, the new economic elites may no longer need the support of the party to guarantee their economic position. It would be rash to say that pressures for political reform and political pluralism will never emerge as a consequence of economic growth and market reforms. However, for now the relationship appears not to be clear-cut, and there is a range of potential scenarios that could take precedence as China evolves.

\section{(Are there any) conclusions}

The path of democratization has not moved smoothly in Asia - indeed, it has not always moved in a single direction. Many regional states share similar challenges - not least the challenge of economic recovery in the wake of the financial crises. But the responses have been very diverse. There is certainly no convincing evidence that a common form of democracy is emerging across the region, nor that democratic politics is necessarily the best or the only way forward. As has been noted above, many people in China 
are at least prepared to tolerate political authoritarianism if it continues to provide a context in which economic advancement occurs.

Even in electoral systems in the region, the type of democracy that has evolved is often constrained by a lack of real choice, a lack of real societal freedom, and state control over sources of information and ideas. It is also constrained by opaque decision-making systems that result from a lack of a separation between public and private, between state and non-state, and between state and market - distinctions that are almost implicitly accepted as the basis for democratization in the West. Accordingly, studies of democratization in East Asia, while not ignoring 'normal' processes of democratization, should also consider the importance of political economy, and that marrying democratization perspectives with those in international political economy specifically offers a particularly appropriate and useful framework for future analyses.

\section{Notes}

1 It is in some ways a great disservice to Polanyi (1944) to reduce the 'Great Transformation' to a single concept. But the key issue of relevance here is his concept of how the industrial revolution fundamentally changed the previous system, where economic relationships were embedded within societal relationships. In particular, this transformation resulted in the separation of economy activity from community-based action, developing into a new institutional separation of politics and economics.

2 The 'Focus on the Global South' can be found on www.focusweb.org. 